\title{
Analysis of Social Media Content used by Travel Portals in India
}

\author{
Anwesha Mukherjee ${ }^{1}$, Dr. Manasa Nagabhushanam ${ }^{2}$ \\ ${ }^{1}$ Research Scholar, Mysore University, ISBR Research Centre, Bangalore \\ ${ }^{2}$ Professor, ISBR Research Centre
}

\begin{abstract}
There's no better way to explore a new location or rediscover a familiar one than by going about armed with recommendations from people who have already travelled to those destinations. Earlier travel agents used this idea to educate potential travellers of what they are to expect when they travel to a particular destination. Today with the advent of Web 2.0 and social media networking, travel portals have proved to the fastest way of connecting like-minded travellers and thereby enabling recommendations from around the world. Traveling enthusiasts aren't shy about sharing any part of their adventures. Travellers are keen to know the cheapest form of travelling and holidaying and the most favourable form of entertainment available at the best rates. Additionally travellers who have already visited the destinations are proud to share their experiences and also warn fellow travellers from potential perils. Travel portals have used this trend in their favour and boomed their existence from being mere travel agents in significant locations to making their presence felt to all over the country. They have created specifically designed websites and applications to assist travellers and their needs. This study has tried to understand the social media content used by the major travel portals in India and identify best practices that will enable the travel industry to grow and thrive. Content analysis has been used to study the social media content used by five major travel portals on their Facebook page. The study has identified a trend in the degree of usage of social media and best practices which will definitely help upcoming travel agents to identify and serve potential travellers. The main limitation of this study is that only five portals have been studied for a period of two months and as a result this study might have missed out on fine strategies used by other portals as well. However, further research done on a greater number of travel portals for a longer time will overcome this limitation. Repeating the same study in a year's time will most likely yield significantly different results, due to the constantly evolving nature of techno-logy and social media.
\end{abstract}

Keywords: Social Media; Facebook; Tourism Destination; Social Media Content; Travel portals; MakeMyTrip, Yatra,com, HolidayIQ, Travel Triangle, Trip Hobo

\section{Introduction}

The 21 st century has proved to be the age of social networking. Today the masses consider you to be primitive or unsocial if you are not connected to any social networking site. In fact, the overall fundamental social structure is changing due to the presence of social networking sites. So what is a social networking site" It is nothing but a website where you can connect with friends, acquaintances, colleagues and strangers alike and exchange ideas, catch up on current news, and also interact with people sitting thousands of miles away from you. It has been a matter of time before certain sections of various social networking sites have started targeting niche members; for example, almost all kinds of industries are resorting to social media to increase their base of consumers. Referring to this area of interest, the travel and tourism industry has also started using social networking sites to promote their products and destinations. Going by the trend social networking seems to have a considerable impact on travel plans and concepts of holidaying.

In the early centuries, the genesis of travelling had more to do with trade, exploration, and conquest. The concept of travelling for leisure or holiday came into existence much later, when we started moving towards an era of civilization that appreciated the finer aspects of life. Over the years human life has become monotonous and stressful and travel seems to be the only way to break this monotony. Today it is rare that a holiday is planned without any professional or external help. Travel and tour agencies have mushroomed to such an extent that it is virtually impossible to bypass them and plan a trip. It used to be restricted to our local travel outlets but with the advent of social media and social networking, they have become an integral part of the world of travel. Today people travel for various reasons, which make it imperative for information sources to be nichebased. A business traveller will have different priorities than a holiday maker. Hence the requirement for travel oriented social networking sites where one can seek information starting from hotels, flights to shopping and places of interest. There are a myriad of social networking sites which are used by travellers. In this study we will study the social media usage of five most popular social networking sites used by travellers and the travel industry at large. This will provide a conceptual view of the kind of practices that are prevalent while interacting with potential travellers in the present world.

\section{Literature Review}

Different methods have been used to collect data on how travel portals are affecting the holiday plans. There was a research conducted by Stephen Joyce, who was the Past Board Chair of the OpenTravel Alliance and currently sits on the Education Advisory Group for the National Tour Association (NTA). According to him, 22\% of travellers who use social media are looking for deals in relation to travel compared to $65 \%$ who look for deals in general. There is no clear indication as to what type of deals these travellers are looking for specifically, but there is a speculation that they are air and hotel deals.

\section{Volume 6 Issue 1, January 2017




\section{International Journal of Science and Research (IJSR) \\ ISSN (Online): 2319-7064 \\ Index Copernicus Value (2015): 78.96 | Impact Factor (2015): 6.391}

What is surprising though is that if this is true, it seems that the users of various travel portals are either not finding deals or are not converting on those deals through the social networks.

Again, based on pure speculation but given that only around $3.5 \%$ of referring traffic to travel websites is coming from social networks in general, it will seem reasonable to assume that these deals are not converting into significant traffic to travel websites.

While travelling, it appears that people are using social media to share their experiences with their friends and family on sites like Facebook, Twitter, Pinterest, and Instagram. It is interesting to note that this behaviour seems to be more impulse driven, since the propensity to share is higher during travel than after travel. So, it ef $^{\text {f }}$ fair to say that people like to use social media in order to share their experiences while travelling.

The travel industry depends a lot on the word of mouth. Social media today gives people a platform to voice their opinion and listen to others just like them from all over the world. Therefore, when a traveller voices his/ her opinion with regards to a travel agent on popular platforms like Twitter, Facebook and Google+, he/ she manages to get hundreds of other people acquainted with the travel agent in question. This acts as a major source of branding for the agent and creates a huge impact on brand awareness. In fact, almost $80 \%$ of the travellers have stated that they believed the recommendations made by their friends and contacts on social media. Jean Newman Glock, president of JNG Worldwide, mentioned that her entire business model revolves around using social media as a major marketing tool to build leads by sharing her passion for travel as well as her travel expertise with her audience.

Many travel agencies spend a lot of money on marketing and branding themselves. However, you can also use social media to market yourself properly in a cheap and economical manner. The travel industry is a service oriented industry and everything works on how satisfied your clients are. Thus, by offering your clients with unique experiences and showcasing their holidays on social media, you can actually transform your business at no extra costs to yourself. Stephanie Diehl, the owner of Travel Designed, mentions that her strategy is to use the social media to share the right kind of information with her audience. She uses social media "to stay top-of-mind" among her customers and believes in posting one post on social media every day. Her posts usually comprise of questions, photos, information or travel advice.

Around 2008, all social media websites had a combined viewership of approximately 2.1 trillion page views. However, this statistic soon increased to mind-boggling numbers. In fact, Facebook alone managed to log about 1 trillion views per month around the year 2010. The dramatic increase of the influence of social media in our daily lives is not surprising at all. Social media has begun to play a huge role - for individuals as well as businesses and organizations - because it helps them to come closer to each other and provides them with a direct channel to interact with each other. Statistics have also shown that almost $46 \%$ of the travellers post their holiday reviews on social media and that $43 \%$ of the travellers actually read these reviews. More than $52 \%$ travellers are largely influenced by social media when it comes to travel planning as well. Thus, using the social media as an opportunity for travel agents has become quite important. This study will analyse how the travel portals use social media to promote their travel products.

The travel portals selected were on the basis of their popularity on social media; the travel portals selected are "MakeMyTrip", "HolidayIQ", "Yatra.Com", "Travel Triangle", and "TripHobo".

MakeMyTrip proposed travellers to think travel and forget about everything else. MakeMyTrip takes care of everything for travellers including, holiday packages, flights, hotels, rail tickets, bus tickets, rented cars. What keeps MakeMyTrip going was enabling and inspiring travellers to discover new places, helping them plan holidays and encouraging them to share their holiday experiences with the community.

HolidayIQ thrives on traveller opinions and travel insights, which have helped them into evolving into a large traveller community since they started out in 2004. With more than 50,000 listed hotels and 2000 destinations, and loads of hotel and holiday reviews shared by travellers daily, HolidayIQ has all the travel information travellers will ever need. No wonder millions of travellers plan their holiday on our website every month. The member of HolidayIQ is entitled to numerous privileges. Travellers can complain about or praise a hotel through a hotel review, tell what they loved or hated about the recent vacation or just tell the world what an awesome photographer they are by sharing pictures and videos narrating their holiday experience. Starting from Beachbums, Heritage Seekers, Foresters, Flashpackers, and many more, the HolidayIQ Traveller Community is brimming with travellers who hail from all corners of India, armed with strong opinions, and share one common passion - the love for travel.

Launched in August 2006, Yatra.com is today ranked as the leading provider of consumer-direct travel services in India. It has emerged as the most trusted travel brand in India. Yatra.com is a one-stop-shop for all travel-related services, a leading consolidator of travel products providing reservation facility for more than 36,000 hotels in India and over 500,000 hotels around the world. Yatra.com provides information, pricing, availability, and booking facility for domestic and international air travel, hotel bookings, and holiday packages along with bus and railway reservations.

Travel Triangle provides personalized holidays that includes offbeat attractions, local cuisines, local activities, village tours or local shopping.

Trip Hobo is a platform to discover great itinerary created by travellers; it enables you to create a itinerary or edit a plan. Trip Hobo is the world 's largest repository of user generated Trip plans. A Trip Plan (Itinerary) contains details of the trip including attractions to be visited, hotels to stay, things to do, and places to eat. Also there are no charges for using Trip Hobo.

\section{Volume 6 Issue 1, January 2017




\section{International Journal of Science and Research (IJSR) \\ ISSN (Online): 2319-7064 \\ Index Copernicus Value (2015): 78.96 | Impact Factor (2015): 6.391}

\section{Problem Statement}

Social media has changed the way travellers plan their travels and holidays. Gone are the days when close friends, neighbours, and relatives provided the only source of inspiration to travel to a particular location. Today social media has widened our horizons and brought the whole world closer. Social media users are motivated by the information shared through popular tools like Facebook, Twitter, etc. They like to explore the destinations even before they actually land here. This has facilitated the rise of many travel portals that have started using social media as a means of marketing the choicest destinations. Travel portals today have taken the place of travel agents and they not only provide information about new destinations, but they also offer attractive deals for all seasons. This leads to a need to understand the social media strategy followed by travel portals and how they intend to make a mark in the mind of potential travellers. There is a need to figure out the trend that is being followed by the major travel portals so that we can come up with best practices to meet future demands. The usage of social media in tourism is a relatively new trend, therefore, the manner and degree with which the travel portals utilise social media as part of their marketing efforts vary considerably. The information, posts, tweets, blog entries, and other forms of content exist freely on the web; however, there has been comparatively little research done to explain the strategies used. This study will focus on lighting up those strategies used by the major travel portals.

\section{Research Questions}

This paper will aim to answer the following research questions based on an extended content analysis of the social media platform used by travel portals:

- RQ1: What is the degree of usage of social media among the top travel portals?

- RQ2: What are the type of posts that contribute to advanced level of social media activity?

- RQ2: What can be the best practices which will help in further promotion of travel destinations?

\section{Research Methodology}

This is an exploratory study and it also adopts an inductive approach in order to explore the nature and degree of the usage of social media amongst tourism destinations. There is a comparison done between the five major travel portals to understand the level of usage of social media content. As suggested by Pearce \& Butler (1993, p.32), it has been seen that comparative studies allow the subjects being researched to ,transfer experiences and learn from others. Keeping this in mind the main focus will be the analysis and interpretation of data collected in the form of content analysis of the five portals. The method of content analysis is the most preferred method since this the interaction method on social media is mainly content and a comparative analysis can only be done when content of all portals are critically analysed.

Further, while choosing which social media platform to analyse for this study, Facebook was selected. With a phenomenal billion-plus membership, Facebook took the internet community by storm and today it is practically unimaginable to ignore Facebook's influence on any business segment. The travel industry is no exception. Today travellers post their observations, interact with fellow travellers, criticize or praise various aspects of travelling through Facebook. Moreover, the introduction of Pages for potential travellers have made a huge difference in terms of reaching the exact target audience. No matter which part of the world you are in, Facebook contains travel related advertisements pertaining to all the destinations and these are spread across travellers located in any part of the world.

Based on the maximum number of followers on Facebook, the travel portals, "MakemyTrip", "HolidayIQ", "Yatra.Com", "TravelTriangle", and "TripHobo" create and maintain an official presence on Facebook and interact with a huge number of consumers through informative articles, travel destination pictures / videos, holiday deals, etc. One month each from the Off Season and Peak Season has been chosen for the analysis to analyse the degree of usage of social media during those months. The study will be conducted for two months, March and April 2016 and based on the data collected during these two months, the conclusion will be drawn.

\section{Sampling Process}

The rationale behind choosing the 5 travel portals were the number of followers they had on Facebook. These portals have been marketing their destinations and the attractions over a long time period of time and they have expanded their efforts to include adopting social media platforms as part of their marketing efforts.

\section{Approach}

A pilot study was done for 15 days in February 2016 which helped in defining the categories that will prove relevant to be investigated through content analysis. The following table has been constructed basis the study which lists the categories in which the Facebook pages will be analysed.

Table 1: Categories defined for Content Analysis

\begin{tabular}{|c|c|c|}
\hline $\begin{array}{l}\text { S. } \\
\text { No. }\end{array}$ & Categories & Sub Categories \\
\hline 1 & $\begin{array}{l}\text { Social Media } \\
\text { Tool }\end{array}$ & Facebook \\
\hline 2 & Posts & $\begin{array}{l}\text { How many posts were posted in March } \\
\text { versus April? (off season / peak season) }\end{array}$ \\
\hline \multirow[t]{2}{*}{3} & \multirow[t]{2}{*}{ Type of Posts } & Informative \\
\hline & & Promotions / Offers \\
\hline 4 & Tags & How many people are tagged? \\
\hline 5 & Likes & How many likes are there on each post? \\
\hline 6 & Shares & How many shares are there on each posts? \\
\hline 7 & Comments & How many comments are there in each post? \\
\hline 8 & Interaction & Is the post interactive? \\
\hline \multirow[t]{3}{*}{9} & \multirow[t]{3}{*}{ External links } & How many posts contained external links? \\
\hline & & Does the post include video? \\
\hline & & Does the post include a link to a website? \\
\hline \multirow[t]{3}{*}{10} & \multirow[t]{3}{*}{$\begin{array}{l}\text { Customer } \\
\text { Service }\end{array}$} & $\begin{array}{l}\text { How many posts were about thanking } \\
\text { travellers / customers? }\end{array}$ \\
\hline & & How many posts requested feedback? \\
\hline & & How many posts responded to some enquiry? \\
\hline
\end{tabular}




\section{International Journal of Science and Research (IJSR) \\ ISSN (Online): 2319-7064 \\ Index Copernicus Value (2015): 78.96 | Impact Factor (2015): 6.391}

One critical component of measuring the impact of social media content in promotion of tourism destinations is the measurement of the number of replies to specific posts. This was easily tracked and analysed on Facebook. The categories defined in Table 1 enabled an analysis of how the travel portals are using social media through the nature, frequency, and reason for posts.

The content analysis of the portals will help in discovering data around the below parameters:
- Categorizing content on the basis of the source of the content

- Categorizing all the content pieces according to the categorization strategy mentioned

- Performing a before-after comparison on the data.

- Extracting conclusions from this data

\section{Results and Discussion}

Based on the analysis of the below mentioned travel portals, the following data has been collected:

Table 2: Basic Statistics for Facebook data collected

\begin{tabular}{|c|c|c|c|c|c|}
\hline Travel Portal Name & Facebook Page Link & No. of Likes & $\begin{array}{c}\text { Member } \\
\text { Since }\end{array}$ & $\begin{array}{c}\text { No. of posts in } \\
\text { March 2016 }\end{array}$ & $\begin{array}{c}\text { No. of posts in } \\
\text { April 2016 }\end{array}$ \\
\hline MakeMyTrip & https://www.facebook.com/makemytrip/posts & $1,905,349$ & 2000 & 500 & 750 \\
\hline Holiday IQ & https://www.facebook.com/holidayiq/posts & $1,710,827$ & 2004 & 186 & 300 \\
\hline Yatra.com & https://www.facebook.com/Yatra/posts & $1,541,783$ & 2006 & 124 & 150 \\
\hline Travel Triangle & https://www.facebook.com/traveltriangle/posts & 350,283 & 2010 & 100 & 140 \\
\hline TripHobo & https://www.facebook.com/TripHobo/posts & 306,030 & 2011 & 120 & 188 \\
\hline
\end{tabular}

Table 3: Most liked Posts

\begin{tabular}{|c|c|c|}
\hline Travel Portal Name & Type of Posts in March 2016 & Type of Posts in April 2016 \\
\hline \multirow[t]{4}{*}{ MakeMyTrip } & Travel Packages $-60 \%$ & Travel Packages $-80 \%$ \\
\hline & Travel Comments $-25 \%$ & Traveller Reviews $-20 \%$ \\
\hline & Hotel Reviews $-15 \%$ & Travel Videos and Pictures $-50 \%$ \\
\hline & Travel Videos $-30 \%$ & \\
\hline \multirow[t]{5}{*}{ Holiday IQ } & Informative Posts $-60 \%$ & Informative Posts $-70 \%$ \\
\hline & Hotel Reviews $-10 \%$ & Hotel Reviews - $10 \%$ \\
\hline & Travel Quotes - 5\% & Travel Quotes - 10\% \\
\hline & Traveller Reviews $-25 \%$ & Food Posts $-10 \%$ \\
\hline & Videos $-30 \%$ & Videos $-40 \%$ \\
\hline \multirow[t]{5}{*}{ Yatra.com } & Holiday Offers $-40 \%$ & Holiday Offers $-50 \%$ \\
\hline & Informative Posts $-20 \%$ & Traveller Comments $-30 \%$ \\
\hline & Food Posts $-10 \%$ & Travel Ideas $-10 \%$ \\
\hline & Hotel Information $-10 \%$ & Visit Information $-10 \%$ \\
\hline & Videos $-20 \%$ & Videos $-50 \%$ \\
\hline \multirow[t]{3}{*}{ Travel Triangle } & Weekend Holiday Packages $-40 \%$ & Holiday plans $-50 \%$ \\
\hline & Hotel Information $-30 \%$ & Food Information $-10 \%$ \\
\hline & Traveller Reviews $-30 \%$ & Tour Packages $-40 \%$ \\
\hline \multirow[t]{3}{*}{ TripHobo } & Trip Planning $-30 \%$ & Itinerary Planning $-40 \%$ \\
\hline & Hotel Price Comparisons $-40 \%$ & Hotel Comparisons $-50 \%$ \\
\hline & Informative Articles - $20 \%$ & Informative Articles - $10 \%$ \\
\hline
\end{tabular}

It was found that today travel planning is dominated by online resources such as reviews and blogs and comments on social networking sites such as Facebook. While analysing each portal as per the identified categories, the following information was collected on a daily basis for each of the five travel portals. The information has been explained through charts and pie diagrams to provide a pictorial representation of the data collected.

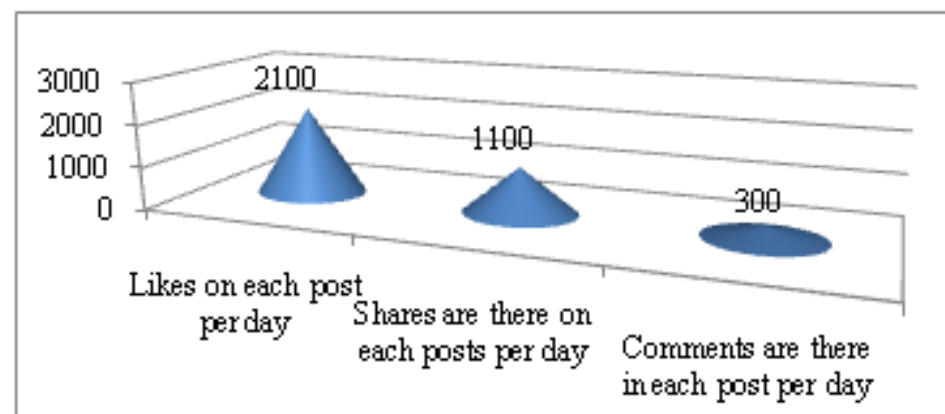

Figure 1: Average no. of Likes / Shares / Comments on MakeMyTrip portal 
International Journal of Science and Research (IJSR)

ISSN (Online): 2319-7064

Index Copernicus Value (2015): 78.96 | Impact Factor (2015): 6.391

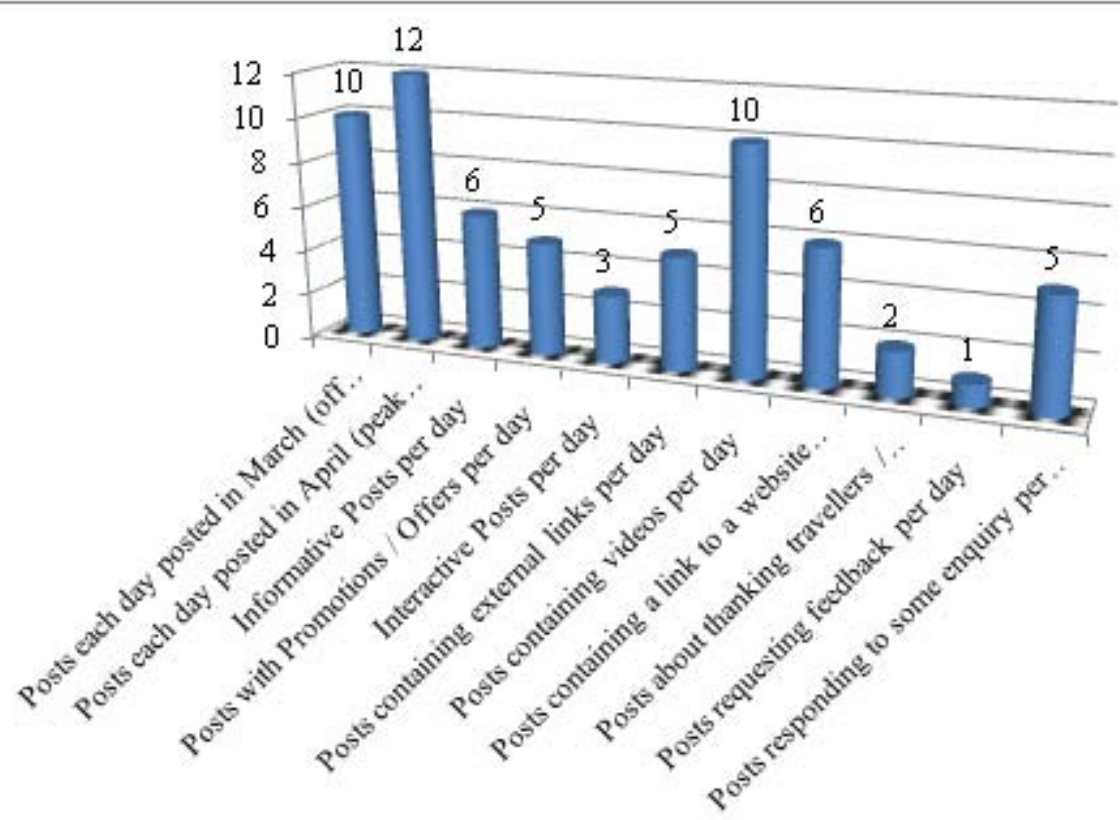

Figure 2: Type of Posts on MakeMyTrip portal on an average

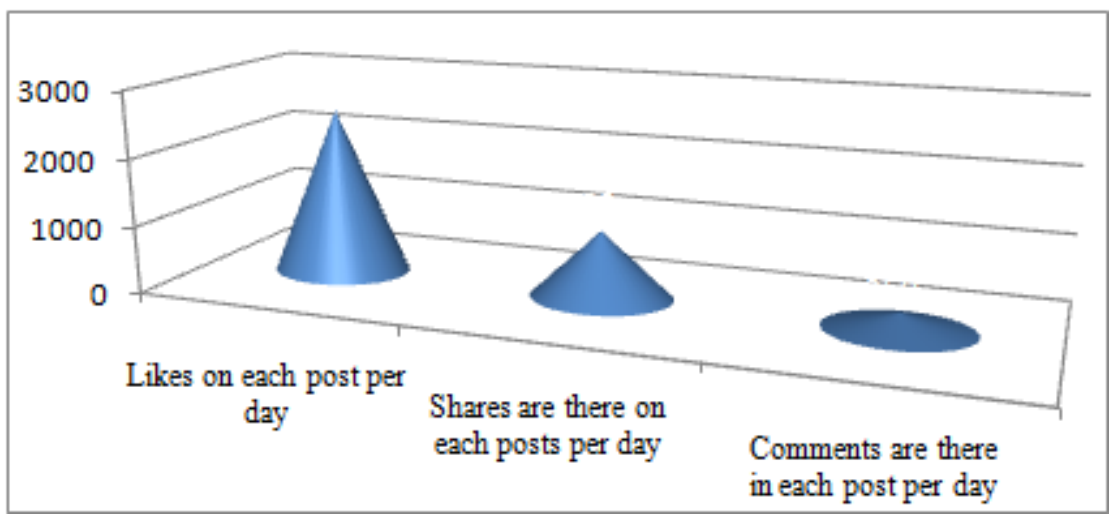

Figure 3: Average no. of Likes / Shares / Comments on HolidayIQ portal

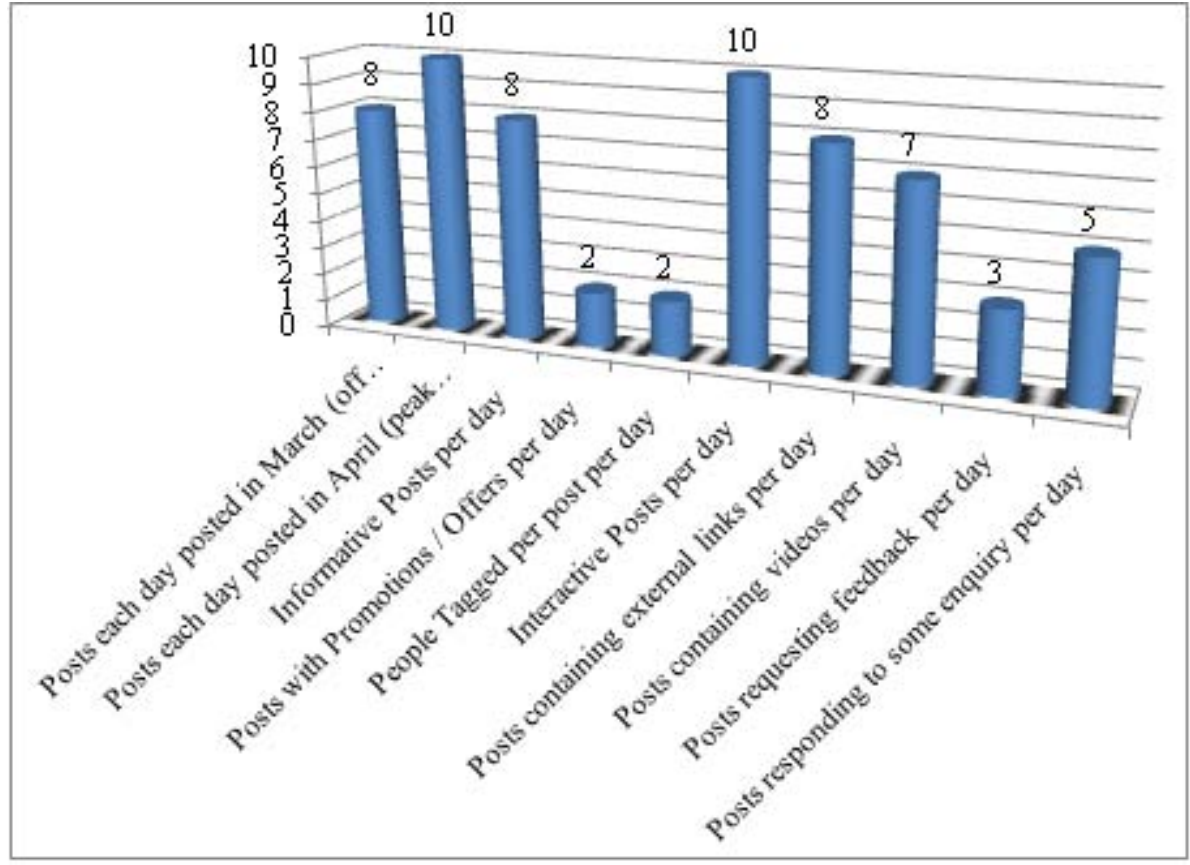

Figure 4: Type of Posts on HolidayIQ portal on an average

Volume 6 Issue 1, January 2017 www.ijsr.net 
International Journal of Science and Research (IJSR)

ISSN (Online): 2319-7064

Index Copernicus Value (2015): 78.96 | Impact Factor (2015): 6.391

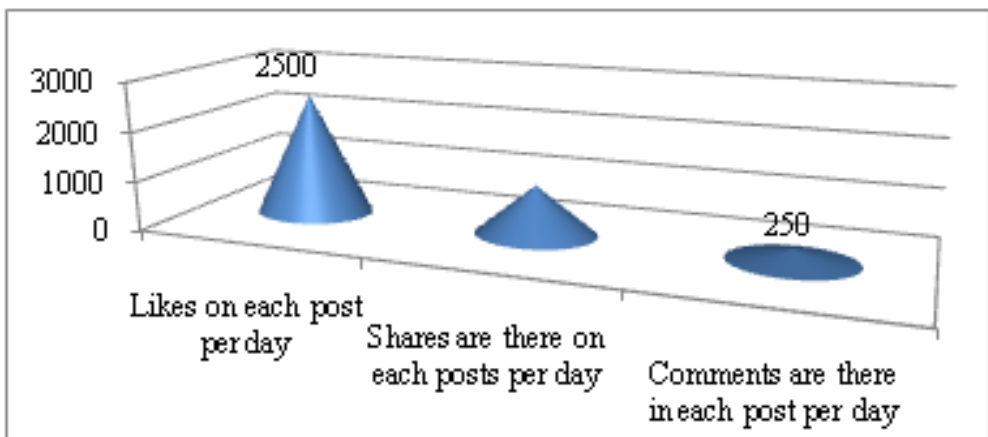

Figure 5: Average No. of Likes / Shares / Comments on Yatra.com portal

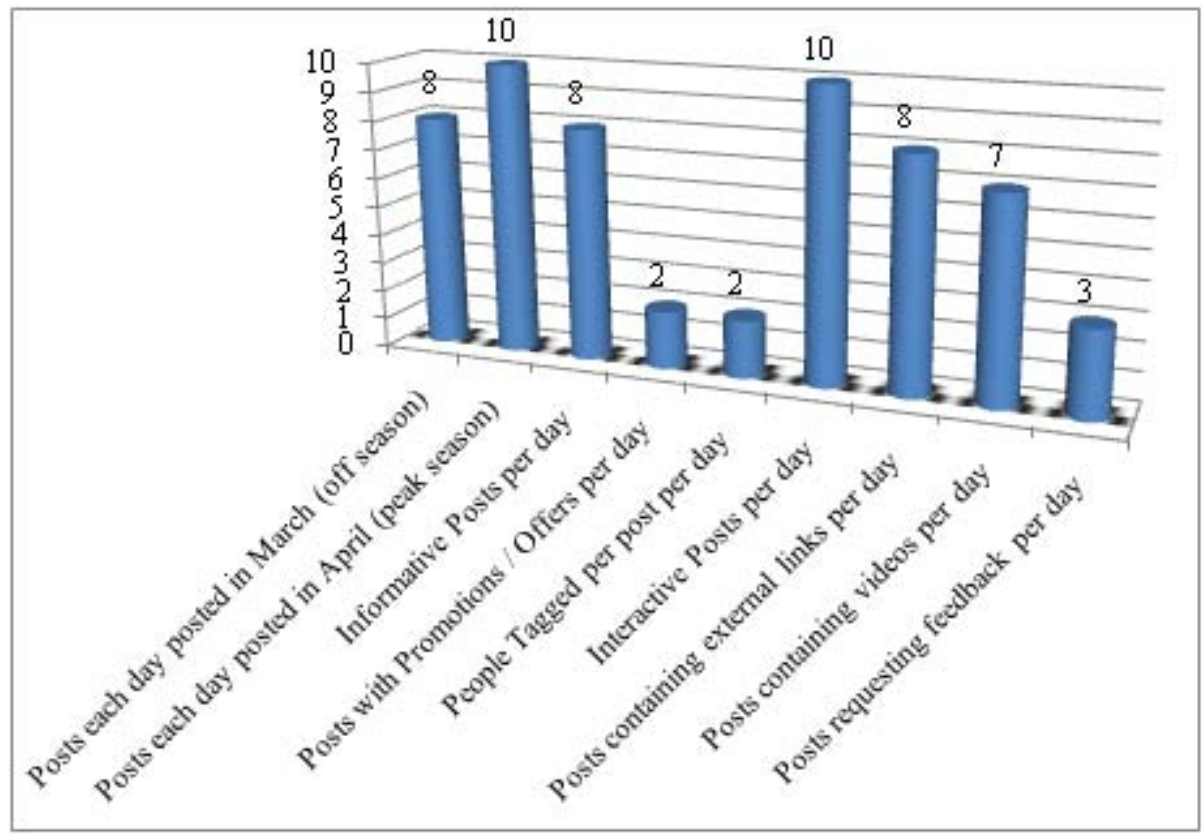

Figure 5:Type of Posts on Yatra.com portal on an average

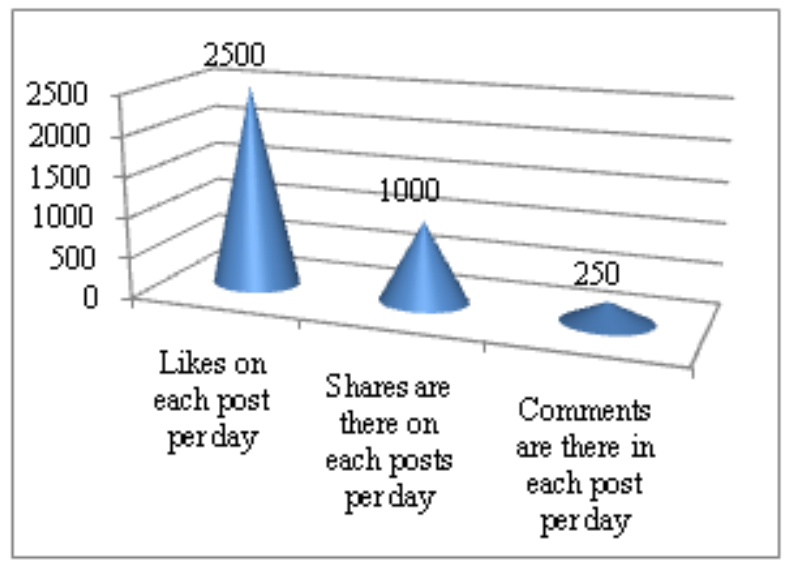

Figure 6: Average No. of Likes / Shares / Comments on Travel Triangle portal 


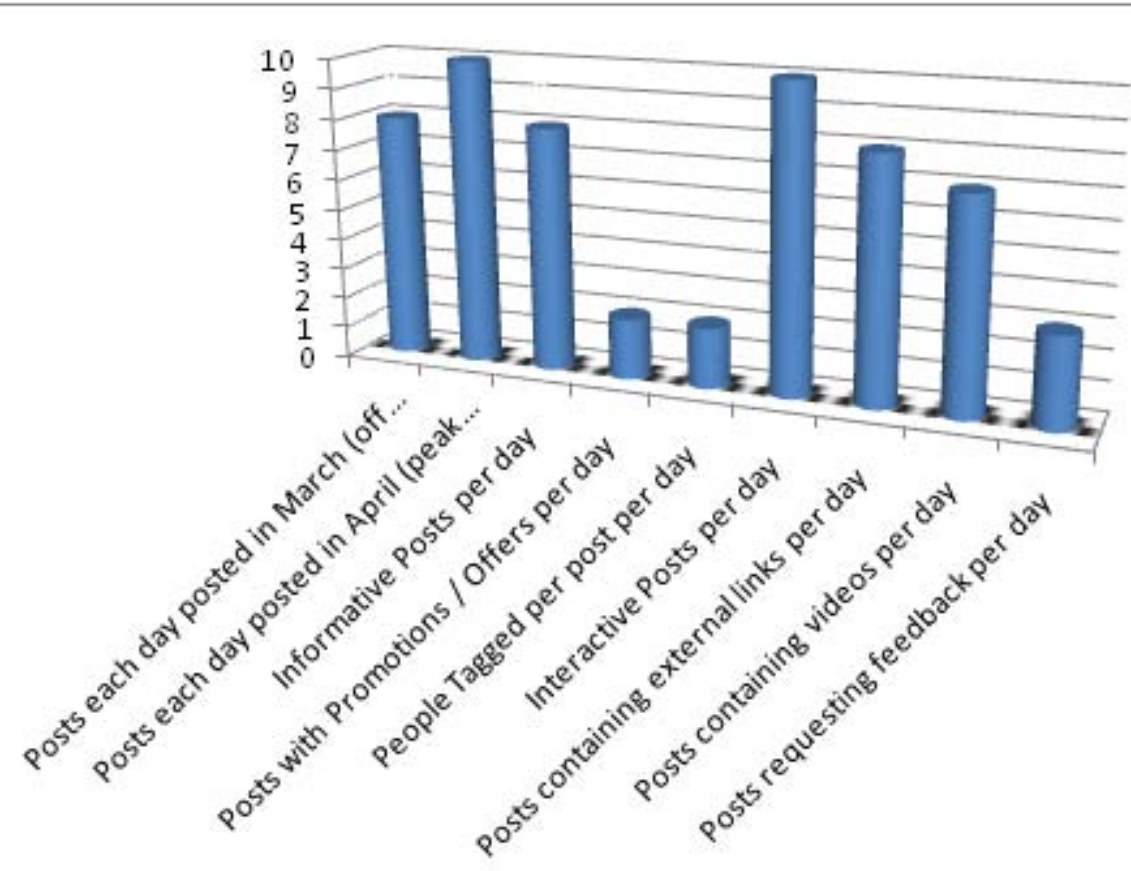

Figure 7: Type of Posts on Travel Triangle portal on an average

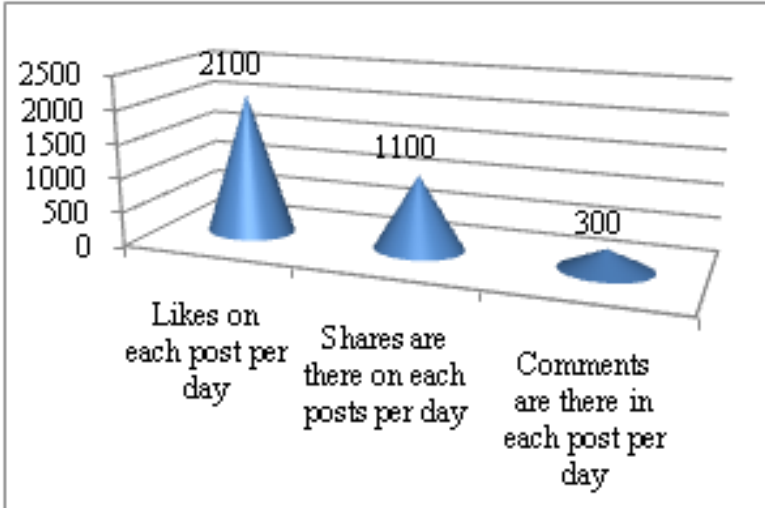

Figure 9: Average No. of Likes / Shares / Comments on Trip Hobo portal

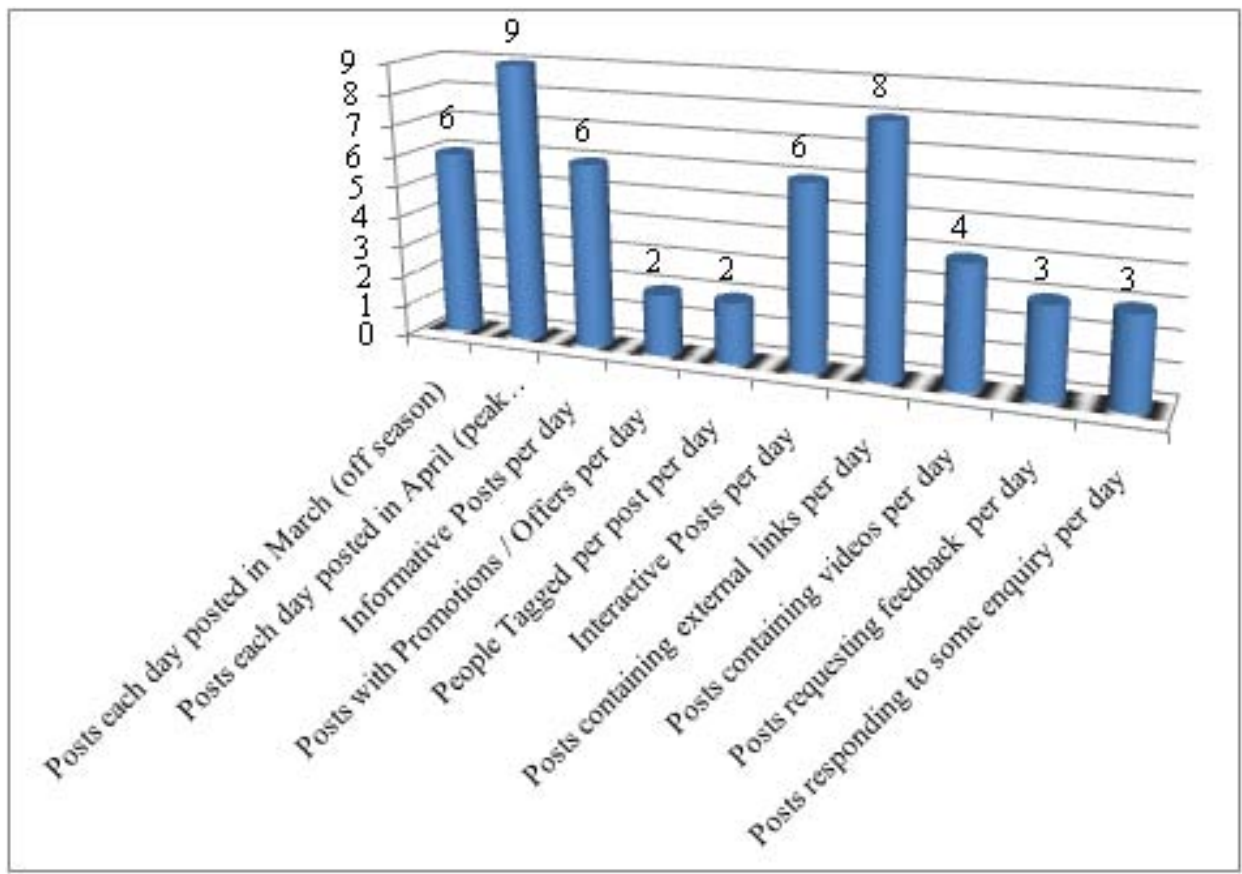

Figure 10: Type of Posts on Trip Hobo portal on an average

Volume 6 Issue 1, January 2017 www.ijsr.net 


\section{International Journal of Science and Research (IJSR) \\ ISSN (Online): 2319-7064}

Index Copernicus Value (2015): 78.96 | Impact Factor (2015): 6.391

\section{Key Findings}

\section{From the Portals Point of View:}

Basis the content analysis of the data related to the Facebook pages of 5 travel portals, "MakeMyTrip", "HolidayIQ", "Yatra.Com", "Travel Triangle", and "Trip Hobo" for two months, a trend has been identified along with various unique attributes.

Some unique attributes:

1) MakeMyTrip surpasses the number of members by almost $100 \%$ from the second most liked portal, Holiday IQ. The benefit is on a higher side for MakeMyTrip as it has been a member of Facebook since 2000 whereas HolidayIQ joined 4 years later in 2004. The other portals in a descending order in the category of number of members is Yatra.com, Travel Triangle, and Trip Hobo.

2) When we take into account the number of posts, MakeMyTrip again proves to be very interactive and regular with 500 posts in the month of March and 750 in the month of April. The fact that summer vacations begin from May seems to be the reason behind the increase of posts by MakeMyTrip.

Trends seen across the five portals:

1) The maximum Facebook posts of all the five portals revolve around announcing travel packages along with holiday contests and offers especially for the upcoming summer vacations

2) The posts revolve around providing information of various holiday destinations, suitable for the summer months

3) Some travel posts focus on providing videos and pictures to attract the potential traveller with strong quotes to attract potential travellers into opening the articles and view the pictures

4) The posts also included information on best / beautiful hotels in both domestic and international destinations

5) Some posts also focused on food available at holiday destinations and the restaurants / hotels where to find them

6) There were posts comparing prices of hotels and focusing on holiday destinations that provide maximum comfort at best prices

7) Some posts displayed reviews by happy travellers and focused on their experiences while booking through the portal

\section{From the Members point of view:}

While analysing the comments from potential travellers, it is seen that younger tourists between the ages of 18 to 24 are more likely to have used Facebook to research and plan their last trip than their older counterparts. As per the findings, $85 \%$ of those who use social media said that interactions between users which include videos, comments and photographs have influenced their travel plans. The majority of the comments proved that travel reviews and opinion of tourists on travel website and online communities influence their travel plans and decision.

\section{Conclusion}

The study summates that there are a number of ways in which a travel agency can use social media in order to make itself more visible and increase its clientele. While analysing the posts of the five travel portals over a period of two months, the following strategies were identified that were used massively by almost all of them.

\section{1) Specializing}

The travel portals have started picking a few destinations or activities and resolved to be a better expert at them than anyone else. Given the fact that consumers now have access to so much travel information, particularly at their fingertips that they have themselves become travel agents, the portals have started demonstrating themselves as a true specialist ready to offer expert advise on the chosen destination.

2) Personalizing

Each of the travel portals have differentiated their selfservice online solutions and are giving their members highly personalized service, recommendations, etc., right from your very first interaction with them.

3) Selling unique experiences

The travel portals have built unique and value added packages, contests, and holiday offers to garner more client access and acceptance.

\section{4) Being complex}

The travel portals have understood that consumers can easily book the simple trips themselves; when they need agents is when they look for complex or customized trips. This is why the posts revolve around customization packages and "Do It Yourself" booking options.

5) Being incredibly responsive and reachable

All the five portals have a fast response time; they respond to queries and feedback within minutes even on weekends because that is the time when most travellers look for holiday plans if any.

\section{Recommendations}

On analysing all the aspects, the study has come up with three best practices that will most certainly help a travel portal get started on social media to promote its products and destinations.

Being a travel agent that travellers can connect with: One of the best ways of using Facebook for promoting travel products is to create a trustworthy brand. The travel portals can easily create a proper online reputation by getting existing customers to share their experiences on the social channels and posting reviews on the Facebook page. The travel agents can keep sharing social media ideas, offer helpful travel tips, and provide customers with unique reads. The right content is likely to help attract more customers.

Offer the right deals: One of the main charms of an online travel portal is its ability to offer customers with exciting deals. Offer customers with last minute deals, car rental bargains, special room rates, and seat sales. This has a major impact on brand awareness for the travel portal. 


\section{International Journal of Science and Research (IJSR) \\ ISSN (Online): 2319-7064}

Index Copernicus Value (2015): 78.96 | Impact Factor (2015): 6.391

Show your expertise as a travel agent: Create bucket lists, use images to convey powerful thoughts, and the expertise as a travel agent to offer potential travellers with more information about refreshing destinations that they can visit during their next holiday. One of the most important roles as a travel agent is to create the need to travel and social media helps to do this seamlessly.

\section{Scope and Limitations}

With more and more businesses getting aboard the digital train to marketing, digital marketing is going to be one of the key aspects of integrated marketing communications of the brands and businesses. Social Media and Digital Marketing will have increased role and impact in travel industry for both suppliers and consumers. This research confirms that travel portals will continue to provide a substantial foundation with which to foster communication among and between travellers and the industry. Social media is still a relatively new, unknown, and most-importantly, a largely unproven technological phenomenon. As the use of social media as a destination marketing tool becomes more widespread, the marketing strategies of travel portals will likely evolve and improve.

The content analysis done for this study will ideally benefit from a longer timeframe, and larger sample size. Were the research to be conducted again, content analysis categories could be expanded accordingly. Repeating the same study in a year's time will most likely yield significantly different results, due to the constantly evolving nature of techno-logy and social media. Additionally, similar research with a larger sample size and time period will provide more comprehensive insights to the use of social media among travel portals. Though the purpose of this study was to explore social media strategies used by the major travel portals, any one of the individual components of this study could be researched as a topic in its own right. For example, further research could be conducted just about the degree of interactivity and engagement of MakeMyTrip on various social media platforms including Instagram, Twitter, etc. As social media usage among travel portals becomes more prevalent, this type of research will be very beneficial. Further, it will be interesting to conduct a similar study with a different sample. For example, identifying potential travellers and understanding their point of view through direct interactions will give us a confirmation that the strategies that have been followed so far as in fact creating the intended impact. This research could also be easily applied to other businesses and/or organisations in the tourism sectors, such as hotels, restaurants, attractions or events. Additional studies related to social media and the tourism sector will obviously aid in providing a broad, wellrounded representation of the social media phenomena. Consequently, a more comprehensive typology of strategies to comparatively study social media usage in tourism will emerge.

\section{References}

[1] Black, L.M. (2011). 5 Creative Facebook marketing campaigns. Retrieved August 21, 2011, from http://mashable.com/2011/01/10/facebookplacescampai gns/

[2] Borges, B. (2009). Marketing 2.0: Bridging the gap between seller and buyer through social media marketing. Tucson, AZ: Wheatmark.

[3] http://blog.indianluxurytrains.com/2013/03/impact-ofsocial-media-on-travel-industry.html

[4] Boyd, D., \& Ellison, N. (2008). Social network sites: Definition, history, and scholarship. Journal of Computer-Mediated Communication, 13, 210 - 230.

[5] Brake, D., \& Safko, L. (2009). The social media bible. Hoboken, NJ: John Wiley and Sons, Inc. Buhalis, D. (1998). Strategic uses of information technologies in the tourism industry. Tourism

[6] Management, 19(5), 409 - 421.

[7] Buhalis, D. (2003). eTourism: Information technology for strategic tourism management. London: Pearson (Financial Times)/Prentice Hall.

[8] Buhalis, D., \& Law, R. (2008). Progress in information technology and tourism management: 20 years on and 10 years after the internet - the state of eTourism research. Tourism Management, 29, $607-623$.

[9] Buss, A., \& Strauss, N. (2009). Online communities handbook: Building your business and brand on the web. Berkeley, CA: New Riders.

[10] Casalo, L.V., Flavian, C., \& Guinaliu, M. (2010). Determinants of the intention to participate in firmhosted online travel communities and effects on consumer behavioural intentions. Tourism Management, 31, $898-911$.

[11]Chung, J., \& Buhalis, D. (2008). Information needs in online social networks. Information Technology \& Tourism, 10, $267-281$.

[12]Facebook.com (2016). Statistics. Retrieved July 2011, from php?statistics

[13]Fisher, T. (2009). ROI in social media: A look at the arguments. Database Marketing \& Customer Strategy Management, 16(3), 189 - 195.

[14] Gretzel, U. (2006). Consumer generated content trends and implications for branding. E-review of Tourism Research, 4(3), $9-11$.

[15] Gretzel, U., Fesenmaier, D.R., Formica, S., \& O'Teary, J.T. (2006). Searching for the future: Challenges faced by destination marketing organizations. Journal of Travel Research, 45(4), 116-126.

[16] Gretzel, U., Yuan, Y., \& Fesenmaier, D. (2000). Preparing for the new economadvertising strategies and change in destination marketing organizations. Journal of Travel Research, 39, $149-156$.

[17] Hjalager, A.-M. (2010). A review of innovation research in tourism. Tourism Management, 31, 1- 12. Jansen, B.J., Zhang, M., Sobel, K., \& Chowdury, A. (2009). Twitter power: Tweets as electronic word of mouth. Journal of the American Society for Information Science and Technology, 60(11),

[18] $2169-2188$.

[19] Kaplan, A.M., \& Haenlein, M. (2009). Users of the world, unite! The challenges and opportunities of social media. Business Horizons, 53, $59-68$.

[20] Krippendorf, K. (1980). Content analysis: An introduction to its methodology. Newbury Park, CA: Sage Publications.

[21] Litvin, S., Goldsmith, R., \& Pan, B. (2008). Electronic 


\section{International Journal of Science and Research (IJSR) \\ ISSN (Online): 2319-7064}

Index Copernicus Value (2015): 78.96 | Impact Factor (2015): 6.391

word-of-mouth in hospitality and tourism management.

Tourism Management, 29, 458 - 468.

\section{Author Profile}

Anwesha Mukherjee has around 7 years across Copy Writing, SEO Content Development, Social Media Marketing, and Research. Presently, she is pursuing $\mathrm{Ph} . \mathrm{D}$. from University of Mysore and working as a Project Manager handling documentation projects for UK / US clients with a team of Technical Analysts and Business Consultants at Tata Consultancy Services.

Dr. Manasa Nagabhushanam has over 10 years of experience in handling research and consulting assignments from corporates, Government and other organizations. She has contributed as a Dean of Amity Global Business School and Director of PESIUP MBA Program in Bangalore, Karnataka. Presently she has set up AnalyZ Research Solutions which provides Market Research support and Analytics solutions. 